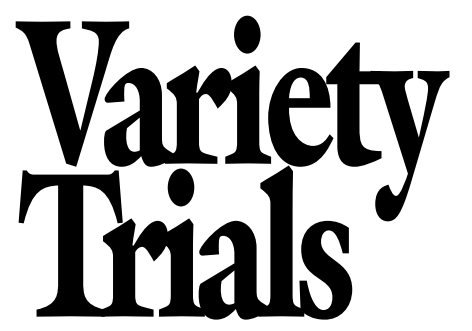

\section{Bacterial Spot Resistance, Yield, and Quality of Bell and Specialty Peppers}

\author{
Brent Rowell, ${ }^{1}$ \\ R. Terry Jones, ${ }^{2}$ \\ William Nesmith, ${ }^{3}$ \\ April Satanek, ${ }^{4}$ and \\ John C. Snyder ${ }^{5}$
}

\begin{abstract}
Additional indeX words. pepper, Capsicum annuum, Capsicum chinense, bacterial leaf spot, Xanthomonas campestris pv. vesicatoria, poblano, anaheim, ancho, jalapeño, cubanelle, wax, serrano, habanero
\end{abstract}

\footnotetext{
University of Kentucky Agricultural Experiment Station Publication no. 01-11-65. The authors gratefully acknowledge the hard work and technical assistance of Darrell Slone, William Turner, Kay Oakley, Dave Lowry, Janet Pfeiffer, and Larry Blansford. We would also like to thank David F. Ritchie and colleagues in the Plant Pathology Department at North Carolina State University for conducting race determination assays in support of this project. The cost of publishing this paper was defrayed in part by payment of page charges. Under postal regulations, this paper therefore must be hereby marked advertisement to indicate this fact.

${ }^{1}$ Associate professor and extension specialist, Dept. of Horticulture, N-318 Agriculture Science North, University of Kentucky, Lexington, KY 40546-0091.

${ }^{2}$ Professor and extension specialist, Department of Horticulture.

${ }^{3}$ Professor and extension specialist, Department of Plant Pathology.

${ }^{4}$ Research analyst, Department of Horticulture.

${ }^{5}$ Associate professor, Department of Horticulture.
}

Summary. Bacterial spot epidemics, caused by Xanthomonas campestris pv. vesicatoria $(\mathrm{Xcv})$, are still considered serious risks for commercial pepper (Capsicum annuum) growers in a number of eastern, southern and midwestern states. Newly released bell pepper cultivars with the $B s 2$ gene for resistance to $X \mathrm{cv}$ races 1,2 , and 3 were compared in 2000 under bacterial spot-free and severe (natural) bacterial spot epidemic conditions in central and eastern Kentucky where similar trials had been conducted from 1995 to 1997 . In addition to the replicated bell pepper trials, 49 hot and specialty pepper cultivars were grown for observation in single plots at the same two locations. As in previous trials, there were economically important differences in resistance and marketable yields among bell pepper cultivars having the $B s 2$ gene; some resistant cultivars were as susceptible as susceptible checks. Others were highly resistant in spite of the presence of $\mathrm{Xcv}$ races 3 and 6 in the eastern Kentucky trial. Only a few were highly resistant with excellent fruit quality. With a few notable exceptions, most of the hot and specialty cultivars were very susceptible to bacterial spot. Two of the three new jalapeño cultivars carrying $B s 2$ were highly resistant to bacterial spot and high yielding under severe epidemic conditions.

B acterial spot or bacterial leaf spot (BLS) caused by Xanthomonas campestris pv. vesicatoria (Xcv) has been a recurring problem for fresh market pepper growers during Kentucky's hot, humid summers. In spite of improvements in the production of transplants and the widespread use of copper and maneb fungicides, BLS control has been unsuccessful during wet growing seasons. Partly as a result of periodic epidemics, about 2000 acres ( 809 ha) of bell peppers are now grown in the state, having declined from its peak of 6000 acres ( 2428 ha) in 1973. States bordering Kentucky also report BLS as their most serious infectious disease of pepper (W. Nesmith, unpublished). For a more thorough discussion of the BLS problem, races of the pathogen, resistance genes, and the development of resistant varieties, see Rowell et al., 1999.

After completing a 3-year (199597) evaluation of bell pepper cultivars under induced BLS and BLS-free environments (Rowell et al., 1999), we began trials in 2000 to compare new cultivars with previously recommended cultivars that were either highly BLSresistant ('Boynton Bell') and/or that had very attractive fruit ('X3R Wizard'). While BLS-resistant pepper cultivars with the $B s 2$ gene (resistance to $\mathrm{Xcv}$ races 1 , 2 , and 3 ) gained widespread acceptance in the state after 1995, a number of new resistant cultivars have been released since then. Because of new regional marketing opportunities, we also screened a large number of hot and specialty peppers (some of which carry the $B s 2$ gene) in single plot trials designed to provide preliminary information to interested growers.

\section{Materials and methods}

Duplicate trials were planted at the Horticultural Crops Research Station in Lexington (LEX) and in eastern Kentucky at the Robinson Experiment Station in Quicksand(QSND). The QSND location is isolated from any commercial pepper production and prone to BLS epidemics. Seventeen bell pepper cultivars were seeded in the greenhouse at LEX on 17 Mar. and 49 hot and speciality cultivars were seeded on 16 Mar. 2000. Seedlings were grown in 72 -cell plastic trays (cell size 1.75 inches $\times 1.75$ inches $(4.5$ by $4.5 \mathrm{~cm})$ ) and transplanted to the field on 16 May (bell cultivars) and 17 May (hot and specialty peppers) at LEX and on 24 May (all types) at QSND. Each LEX trial received $70 \mathrm{lb} /$ acre $\left(78 \mathrm{~kg} \cdot \mathrm{ha}^{-1}\right)$ of $\mathrm{N}$ before planting supplemented by an additional $64 \mathrm{lb} /$ acre $\left(72 \mathrm{~kg} \cdot \mathrm{ha}^{-1}\right)$ of $\mathrm{N}$ fertigated in 7 to $10 \mathrm{lb} /$ acre $(7.8$ to 11.2 $\left.\mathrm{kg} \cdot \mathrm{ha}^{-1}\right)$ increments at weekly or biweekly intervals throughout the season [134 lb/acre $\left(150 \mathrm{~kg} \cdot \mathrm{ha}^{-1}\right)$ total $\mathrm{N}$ ]. Each trial at QSND received a total of $70 \mathrm{lb} /$ acre $\left(78 \mathrm{~kg} \cdot \mathrm{ha}^{-1}\right)$ of $\mathrm{N}$ fertigated in $15 \mathrm{lb} /$ acre $\left(16.8 \mathrm{~kg} \cdot \mathrm{ha}^{-1}\right)$ increments at weekly intervals during the growing season. $\mathrm{P}$ and $\mathrm{K}$ were applied broadcast before planting at recommended rates according to soil test results at both locations.

Plots at each location consisted of 16 plants in double rows. Bell pepper plots were established with four replications in a randomized complete block design whereas hot and specialty peppers were grown in single plots. Transplants were planted into raised beds with black plastic mulch and drip irrigation [8-mil (0.008-inch, 0.2-mm) TTape, (T-Systems International, San Diego, Calif.) with 12 inches $(30 \mathrm{~cm})$ 


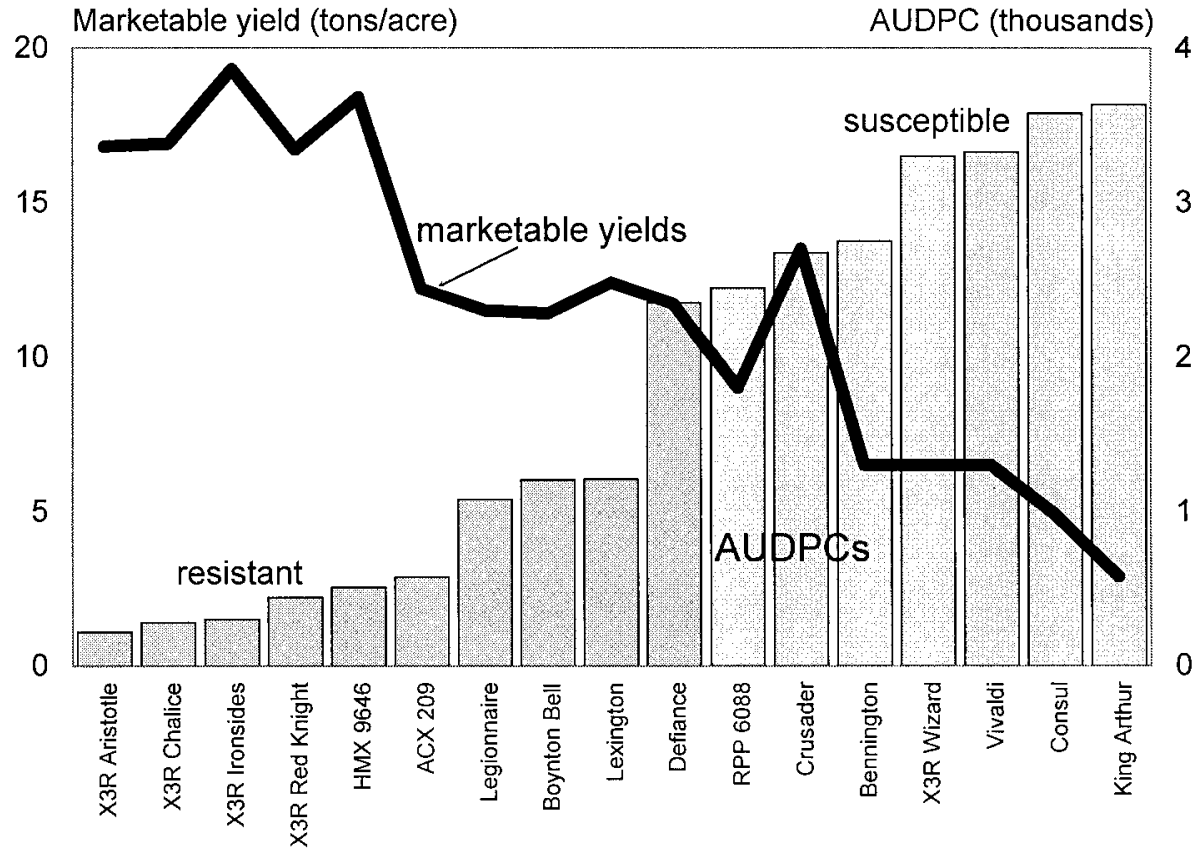

Fig.1. Relationship between total marketable yields ( 1 ton/acre $=2.24 \mathrm{t} \cdot \mathrm{ha}^{-1}$ ) and bacterial spot epidemic development (AUDPC) on 17 bell pepper cultivars. Data plotted are means of four replications from a trial exposed to a severe natural epidemic at Quicksand, Ky., in 2000. between emitters]. Plants of all cultivars were spaced 12 inches $(30 \mathrm{~cm})$ apart in the row with 15 inches $(38 \mathrm{~cm})$ between the two rows on each bed. Beds were 6 $\mathrm{ft}(1.8 \mathrm{~m})$ apart from center to center. At Lexington, fixed copper (either Kocide 2000 or TennCop 5E, a.i. at $1 \mathrm{lb} /$ acre, $1.1 \mathrm{~kg} \cdot \mathrm{ha}^{-1}$ ) was applied weekly as a foliar spray for BLS control beginning 26 May.

No fungicides or bactericides were applied at QSND in order to encourage the development of a natural BLS epidemic. Susceptible jalapeño pepper cultivars were planted as guard rows on both sides of the bell and hot/specialty pepper fields at QSND. In contrast to previous trials at QSND, we relied on natural disease development and did not inoculate with Xcv. Before a pumpkin (Cucurbita pepo) planting in 1999 , the field where both trials were located at QSND had been in sod for 30 years; peppers had not been grown at that research station since 1997. Plots at both locations were treated with

Table 1. Yields, gross returns, and appearance of bell pepper cultivars under bacterial spot-free conditions in Lexington, Ky.; yield and returns data are means of four replications.

\begin{tabular}{|c|c|c|c|c|c|c|c|c|c|}
\hline Four $S \operatorname{tar}(B s 2)$ & RG & 32.1 & 40 & 13193 & 2 & 5 & $3-4$ & 0.29 & $\lg$ \\
\hline Consul & HM & 32.0 & 34 & 12996 & 3 & 6 & $3-4$ & 0.30 & $\mathrm{mg}$ \\
\hline X3R Aristotle $(B s 2)$ & PS & 31.5 & 46 & 13065 & 3 & 6 & 4 & 0.34 & $\mathrm{mg}$ \\
\hline Lexington $(B s 2)$ & AS & 30.7 & 51 & 12851 & 2 & 4 & $3-4$ & 0.31 & $\mathrm{mg}-\mathrm{dg}$ \\
\hline Crusader $(B s 2)$ & RG & 30.6 & 40 & 12418 & 2 & 4 & $3-4$ & 0.28 & $\mathrm{mg}-\mathrm{dg}$ \\
\hline King Arthur $(B s I)$ & PS & 30.6 & 46 & 12323 & 2 & 5 & 4 & 0.28 & $\lg$ \\
\hline Boynton Bell $(B s 2, B s I)$ & $\mathrm{HM}$ & 30.0 & 46 & 12409 & 3 & 6 & $3-4$ & 0.28 & $\mathrm{mg}-\mathrm{dg}$ \\
\hline Bennington & AS & 29.4 & 56 & 12258 & 3 & 7 & 4 & 0.31 & $\mathrm{dg}$ \\
\hline $\operatorname{ACX} 209(B s 2)$ & $\mathrm{AC}$ & 26.7 & 43 & 11092 & 4 & 7 & $3-4$ & 0.28 & $\mathrm{mg}$ \\
\hline Legionnaire $(B s 2)$ & RG & 26.0 & 40 & 10793 & 3 & 6 & 4 & 0.29 & $\mathrm{mg}$ \\
\hline Vivaldi & $\mathrm{VL}$ & 16.1 & 42 & 6685 & 3 & 6 & 4 & 0.31 & red \\
\hline$\overline{\text { Waller-Duncan LSD }(P<}$ & $<0.05)$ & 4.5 & 15 & 1933 & & & & & \\
\hline
\end{tabular}

${ }^{\mathrm{z}} \mathrm{RG}=$ Rogers Brand (Novartis Seeds), Boise Idaho; HM = Harris Moran Seed Co., Modesto, Calif.; PS = Petoseed (Seminis Vegetable Seeds), Saticoy, Calif.; AS = Asgrow Seed Co. (Seminis Vegetable Seeds), Saticoy, Calif.; AC = Abbott \& Cobb Seed Co., Feasterville, Pa.; VL = Vilmorin Inc., Empire, Calif.

yTotal marketable yield included yields $\left(1 \mathrm{ton} / \mathrm{acre}=2.24 \mathrm{t} \cdot \mathrm{ha}^{-1}\right)$ of U.S. Fancy and No. 1 fruit of medium $[>2.5$ inches diameter $(>64$ mm $)]$ size and larger plus misshapen but sound fruit which could be sold as choppers to foodservice buyers.

xercentage of total yield that was extra-large [XL, $>3.5$ inches diameter $(>89 \mathrm{~mm})]$ and large $[>3$ inches diameter $(76 \mathrm{~mm})$ but $\leq 3.5$ inches diameter].

${ }^{\mathrm{w}}$ Gross returns per acre $(\$ 1 / \mathrm{acre}=\$ 2.47 / \mathrm{ha})$; average 2000 season local wholesale prices were multiplied by yields from different size $/$ grade categories: $\$ 0.21 / \mathrm{lb}(\$ 0.46 / \mathrm{kg})$ for extra-large and large, $\$ 0.16 / \mathrm{lb}(\$ 0.35 / \mathrm{kg})$ for mediums, and $\$ 0.13 / \mathrm{lb}(\$ 0.29 / \mathrm{kg})$ for choppers, i.e., misshapen fruit.

vAverage visual uniformity of fruit shape where $\mathrm{l}=$ least uniform, $5=$ completely uniform.

"Visual fruit appearance rating where $\mathrm{l}=$ worst, 9 = best, taking into account overall attractiveness, shape, smoothness, degree of flattening, color, and shape uniformity; all fruit from all four replications observed at the fourth harvest (10 Aug.)

${ }^{t} 3-4=$ about half and half three and four-lobed; $4=$ mostly four-lobed.

${ }^{\mathrm{s}}$ Average wall thickness $(0.1$ inch $=0.25 \mathrm{~cm})$ from five typical fruit from one harvest.

rYellow at maturity.

$\mathrm{q}_{\mathrm{lg}}=$ light green; $\mathrm{mg}=$ medium green; $\mathrm{dg}=$ dark green 
Table 2. Description of new single plot trial rationale and protocol.

Rapid action cultivar evaluation (RACE) trials are

- A means of getting new information to growers in the least amount of time.

- A cultivar or cultural practice trial without replication or with a maximum of two replications.

- Trials in which preferably the same set of cultivars can be replicated by location; grown on-station and/or in growers' fields.

- Appropriate for new crops for which the market potential is unknown or in some cases for existing crops with small niche market potentials.

- Appropriate for screening a large number of cultivars (not breeding lines) of unknown adaptation.

- Appropriate for home garden cultivars (i.e., expensive replicated trials may not be appropriate for home garden cultivars in many cases).

- A means of quickly responding to new questions about specialty crops without compromising replicated trials with priority crops.

- Provide growers with a general idea of cultivars' relative performance, suitability for market, cultural requirements, picking difficulty, etc.

How do RACE trials differ from observation trials conducted in the past?

- RACE trials are put on the best and most uniform plot ground and are well maintained, sprayed, irrigated, etc; they do not serve as guard rows for other replicated trials.

- Crops are harvested at the appropriate time with accurate record keeping, yield data, quality information. Results are reported/published as are replicated trial results.

- Whenever possible, products are evaluated with assistance and standards from knowledgeable marketers, interested produce buyers, growers.

- Information obtained should not be used to identify one or more 'best' cultivars but to eliminate the worst from further testing; a group of cultivars can be recommended for further testing by interested growers.

permethrin or acephate for European corn borer (Ostrinianubilalis) and aphid (family Aphididae) control as needed.

Eleven new bell cultivars with the Bs 2 gene (Table 1) were compared with resistant controls 'Boynton Bell' and 'X3R Wizard' and with a susceptible control, 'King Arthur' (Bsl only). 'Bennington' was reported to possess Bs 2(resistance to Xcv races 1 to 3 ) when this trial was conducted; however, Seminis plant breeders later discovered that 'Bennington' in fact did not have Bs2.

Mature green fruit were harvested

Table 4. Yield and fruit observations from single plots of jalapeño pepper cultivars, Lexington, Ky.

\begin{tabular}{|c|c|c|c|c|c|c|}
\hline \multirow[b]{3}{*}{$\begin{array}{l}\text { Cultivar } \\
\text { (resistance gene) }\end{array}$} & & \multirow{3}{*}{$\begin{array}{c}\text { Marketable } \\
\text { yield } \\
\left.\text { (tons/acre }^{y}\right)\end{array}$} & \multirow[b]{3}{*}{$\mathbf{B L S}^{\mathbf{x}}$} & \multicolumn{3}{|c|}{ Fruit characteristics } \\
\hline & & & & \multicolumn{3}{|c|}{ Avg $^{\text {w }}$} \\
\hline & $\begin{array}{c}\text { Seed } \\
\text { source }^{\mathrm{z}}\end{array}$ & & & $\begin{array}{l}\text { Length } \\
\text { (inch) }\end{array}$ & $\begin{array}{r}\text { Diam } \\
\text { (inch) }\end{array}$ & $\begin{array}{l}\text { Wt } \\
\text { (g) }\end{array}$ \\
\hline Hybrid No. 7 & RU & 42.0 & 1 & 3.3 & 1.4 & 33 \\
\hline Grande & PS & 38.3 & & 3.5 & 1.3 & 33 \\
\hline X3R Ixtapa (Bs2) & PS & 38.0 & & 3.1 & 1.2 & 28 \\
\hline RPP 7042-VP & $\mathrm{RG}$ & 37.1 & & 3.5 & 1.1 & 26 \\
\hline Pecos & $\mathrm{RG}$ & 36.0 & 2 & 3.3 & 1.2 & 31 \\
\hline Ballpark & PS & 34.7 & 1 & 3.9 & 1.1 & 30 \\
\hline Coyame & PS & 34.3 & & 3.2 & 1.2 & 31 \\
\hline Mitla & PS & 34.3 & & 2.9 & 1.2 & 26 \\
\hline Dulce & PS & 33.2 & 1 & 3.3 & 1.2 & 26 \\
\hline Sayula (Bs2) & PS & 33.1 & & 3.3 & 1.1 & 24 \\
\hline El Ray (Bs2) & $\mathrm{SK} / \mathrm{SW}$ & 32.7 & & 3.3 & 1.3 & 30 \\
\hline Tula & PS & 31.9 & 3 & 3.4 & 1.3 & 36 \\
\hline Perfecto & $\mathrm{HN} / \mathrm{AS}$ & 31.5 & & 3.3 & 1.3 & 28 \\
\hline Sierra Fuego & $\mathrm{H}$ & 31.0 & 2 & 2.7 & 1.2 & 24 \\
\hline Delicias & PS & 29.0 & 3 & 2.8 & 1.1 & 26 \\
\hline Summer Heat 5000 & $\mathrm{AC}$ & 26.8 & & 3.1 & 1.2 & 27 \\
\hline Tam Jalapeno No. 1 & $\mathrm{RG} / \mathrm{PS}$ & 24.4 & & 2.8 & 1.1 & 19 \\
\hline
\end{tabular}

${ }^{\mathrm{z}} \mathrm{RU}=$ Rupp Seeds, Wauseon, Ohio; RG = Rogers Brand (Novartis Seeds), Boise Idaho; PS = Petoseed (Seminis Vegetable Seeds), Saticoy, Calif.; AS = Asgrow Seed Co. (Seminis Vegetable Seeds), Saticoy, Calif.; AC = Abbott \& Cobb Seed Co., Feasterville, Penn.; SW = Seedway, Elizabethtown, Pa.; HN = HungNong Seed America, Gilroy, Calif.; $\mathrm{H}=$ Hollar \& Co., Rocky Ford, Colo.

yl ton $/$ acre $=2.24 \mathrm{t} \cdot \mathrm{ha}^{-1}$

${ }^{x}$ Bacterial spot symptoms were observed in some plots and may have affected yields of those cultivars: $1=$ plots with mild infection, $2=$ plots with mild to moderate infections, 3 = plots that had moderate to severe infections. A blank in this column indicates that no symptoms were observed; blanks or numbers do not imply resistance or tolerance.

wAverage of a sample of 10 fruit (length and width, 1 inch $=2.54 \mathrm{~cm}$ ); $1 \mathrm{~g}=0.04 \mathrm{oz}$

vAverage wall thickness of five typical fruit from one harvest $(0.1$ inch $=0.25 \mathrm{~cm})$.

"Visual fruit appearance ratings where $1=$ worst, $9=$ best, taking into account overall attractiveness, shape, color, and uniformity .

$\mathrm{tg}=$ light green; $\mathrm{mg}=$ medium green; $\mathrm{dg}=$ dark green; $\mathrm{vdg}=$ very dark green .

defoliated; averages from two assessment dates.

${ }^{\mathrm{x}} \mathrm{l}$ ton/acre $=2.24 \mathrm{t} \cdot \mathrm{ha}^{-1}$ 
Table 3. Yields, gross returns, and disease resistance of bell pepper cultivars exposed to a severe bacterial spot epidemic, Quicksand, Ky; data are means of four replications.

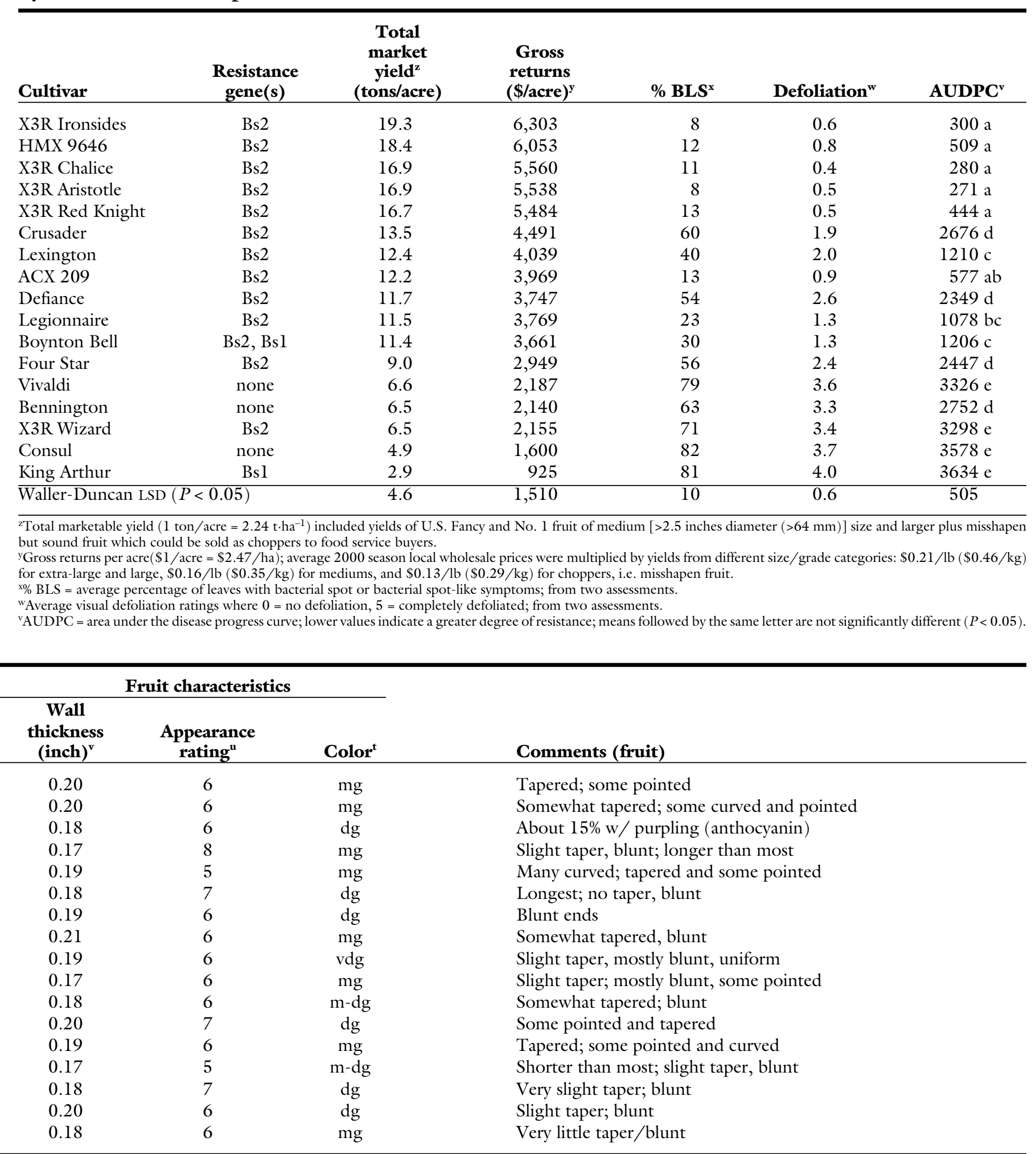


Table 5.Disease resistance and yield observations from single plots of specialty pepper cultivars under severe bacterial spot epidemic conditions, Quicksand, Ky.

\begin{tabular}{|c|c|c|c|}
\hline $\begin{array}{l}\text { Type } \\
\text { Cultivar } \\
\text { (resistancegene) } \\
\end{array}$ & $\% \mathbf{B L S} \mathbf{z}^{\mathbf{z}}$ & Defoliation $^{\mathrm{y}}$ & $\begin{array}{c}\text { Marketable } \\
\text { yield } \\
\left.\text { (tons/acre }^{\mathrm{x}}\right)\end{array}$ \\
\hline \multicolumn{4}{|l|}{ Jalapeño } \\
\hline X3R Ixtapa (Bs2) & 3 & 0.0 & 9.7 \\
\hline El Ray (Bs2) & 22 & 1.0 & 6.9 \\
\hline Hybrid No. 7 & 85 & 4.0 & 5.1 \\
\hline RPP 7042-VP & 62 & 3.5 & 5.0 \\
\hline Grande & 82 & 3.5 & 3.9 \\
\hline Sierra Fuego & 80 & 4.0 & 3.1 \\
\hline Coyame & 82 & 4.0 & 3.0 \\
\hline Ballpark & 75 & 3.2 & 2.7 \\
\hline Sayula (Bs2) & 10 & 0.5 & 2.5 \\
\hline Pecos & 75 & 3.2 & 2.5 \\
\hline Dulce & 67 & 3.5 & 2.3 \\
\hline Summer Heat 5000 & 85 & 4.0 & 2.2 \\
\hline Delicias & 80 & 4.5 & 2.0 \\
\hline Mitla & 80 & 4.0 & 1.9 \\
\hline Perfecto & 80 & 3.5 & 1.7 \\
\hline Tam Jalapeño No. 1 & 80 & 3.5 & 1.7 \\
\hline Tula & 87 & 4.5 & 1.5 \\
\hline \multicolumn{4}{|l|}{ Serrano } \\
\hline Tampico Fiesta & 10 & 1.0 & 2.6 \\
\hline Serrano Chili & 3 & 0.0 & 2.1 \\
\hline Tuxtlas & 60 & 3.5 & 0.9 \\
\hline Serrano Tampiqueno & 45 & 2.0 & 0.4 \\
\hline \multicolumn{4}{|l|}{ Anaheim } \\
\hline Mexiheim & 72 & 3.5 & 2.8 \\
\hline Garden Salsa & 75 & 4.0 & 1.5 \\
\hline Anaheim TMR 23 & 80 & 4.0 & 0.2 \\
\hline \multicolumn{4}{|l|}{ Poblano/Ancho } \\
\hline Ancho San Martin & 62 & 3.0 & 1.6 \\
\hline Ancho Villa & 67 & 3.5 & 1.0 \\
\hline Ancho 101 & 85 & 5.0 & 0.2 \\
\hline Ancho Gigantia & 72 & 5.0 & 0.1 \\
\hline Ancho Ranchero & 80 & 4.0 & 0.0 \\
\hline \multicolumn{4}{|l|}{ Italian/Cubanelle } \\
\hline Aruba & 40 & 2.7 & 5.1 \\
\hline Corno Di Toro & 77 & 4.0 & 1.7 \\
\hline Biscayne & 67 & 3.5 & 0.8 \\
\hline ACX 500 & 72 & 4.0 & 0.7 \\
\hline Giant Aconcagua & 75 & 4.0 & 0.1 \\
\hline \multicolumn{4}{|l|}{ Hot banana/wax } \\
\hline X3R Hot Spot (Bs2) & 17 & 1.0 & 6.7 \\
\hline Romanian Hot Hybrid & 52 & 3.0 & 6.4 \\
\hline Hungarian Yellow Wax & 40 & 2.5 & 4.8 \\
\hline ACX 400 & 42 & 2.5 & 4.0 \\
\hline Hungarian Heat & 65 & 3.5 & 3.4 \\
\hline Inferno & 80 & 4.0 & 2.1 \\
\hline Santa Fe Grande & 50 & 2.5 & 1.7 \\
\hline \multicolumn{4}{|l|}{ Sweet banana/wax } \\
\hline Market Sweet & 67 & 3.5 & 6.1 \\
\hline Pageant (Bs2) & 62 & 3.5 & 5.4 \\
\hline Gypsy & 72 & 3.0 & 4.6 \\
\hline Sweet Banana & 65 & 4.0 & 2.5 \\
\hline Banana Supreme & 75 & 4.0 & 2.4 \\
\hline \multicolumn{4}{|l|}{ Miscellaneous } \\
\hline Habanero & 22 & 1.0 & 2.9 \\
\hline Super Chili & 25 & 2.0 & 2.8 \\
\hline Mesilla & 62 & 3.5 & 1.7 \\
\hline
\end{tabular}

$\overline{\mathrm{z} \% \mathrm{BLS}}=$ average percentage of leaves with bacterial spot or bacterial spot-like symptoms; data are averages from two assessment dates.

${ }^{y}$ Visual leaf drop (defoliation) ratings where $0=$ no defoliation and $5=$ completely five times in LEX and three times at QSND. Marketable fruit were sorted by size, counted, and weighed. Marketable size classes were U.S. No. 1 extra large $(>3.5$ inches in diameter $(>8.9 \mathrm{~cm})$ ), large ( $>3$ inches but $\leq 3.5$ inches in diameter $(>7.6 \mathrm{~cm}, \leq 8.9 \mathrm{~cm}))$, and medium $(>2.5$ inches but $\leq 3$ inches in diameter $(>6.2 \mathrm{~cm}, \leq 7.6 \mathrm{~cm}))$. Misshapen fruit of any size which could have been marketed to foodservice as choppers were also weighed. Yields in each size class were multiplied by their respective wholesale market prices to determine gross returns for each cultivar. The gross returns variable has been a good indicator of a cultivar's overall performance, taking into account yields of the different size classes and their price differentials (Rowell et al., 1999). Means of all variables were compared within each location using WallerDuncan's LSD (k ratio $t$ tests, $P=0.05$ ).

RACE TRIALs. In order to screen a very large number of cultivars of unknown adaptation, we grew hot and specialty peppers in single plots at both locations employing a rapid response approach which we have termed a RACE trial (Rapid Action Cultivar Evaluation, Table 2). Although no statistical comparisons are possible, most of the worst cultivars are eliminated from further testing and useful preliminary information is provided to growers responding to new marketing opportunities. Included in these trials were 16 jalapeño cultivars, three carrying Bs2 ['Sayula', 'El Ray' (SAX 7603), 'X3R Ixtapa']; several other jalapeño cultivars were described as having multiple virus resistance. These were compared with 'Mitla' which had been the best performer in previous jalapeño trials. Other pepper types included four serrano cultivars, three anaheim cultivars, five poblano/ ancho cultivars, five Italian/cubanelle cultivars, seven hot banana/wax cultivars, five sweet banana/wax cultivars, and three miscellaneous types. Two of the banana pepper cultivars had $B s 2$ for BLS resistance ('X3R Hot Spot', 'Pageant').

Fruit appearance ratings. All fruit of each bell pepper cultivar from all four replications from the fourth harvest (10 Aug) at LEX were laid out on the ground for examination and quality rating. All fruit from single plots of hot and specialty peppers were examined and rated in the same manner. Overall appearance ratings represented, in order of importance: overall attractiveness, 
shape, smoothness, degree of flattening (bell cultivars), and color. Uniformity of shape was also rated and the number of lobes recorded for bell pepper cultivars. Fruit wall thickness was measured with dial calipers on five typical fruit selected from one replication at midseason. Fruit length and width of 10 typical fruit of hot and specialty pepper cultivars were also measured; average fruit weights were determined by dividing seasonlong total marketable yields by the total numbers of marketable fruit.

Plant support requirements. Under our growing conditions (close spacings, double rows, plastic mulch, drip irrigation), some of the hot and specialty pepper cultivars required staking and tying. All specialty cultivars at LEX were inspected at maximum fruit load to determine if staking and tying were needed. Tomato stakes (shorter stakes could also have been used) were driven into the ground at the four corners of individual plots; plants were fenced in by running a string (tomato twine) around these four stakes. A single stringing was adequate for some cultivars while others required two or three successive stringings.

Disease assessments and risk. Disease reaction was measured in the QSND bell and specialty pepper trials by visual estimates of the percentage of leaves exhibiting BLS or BLS-like lesions (percent BLS) and by rating the plants for the extent of leaf drop (0 to 5 scale where $0=$ no defoliation; $5=$ total defoliation). All plots at QSND were assessed on 16 July and 2 Aug. Percentage assessments (\% BLS) were used to calculate the area under the disease progress curve (AUDPC) for each bell pepper cultivar (Campbell and Madden, 1990). This variable is routinely used by plant pathologists to describe or compare epidemics; higher values indicate more severe epidemic conditions (lower host plant resistance). AUDPC values were considered together with percent BLS and defoliation ratings as overall indicators of resistance. The presence/absence and severity of BLS symptoms were also recorded from hot/ specialty cultivars at LEX on 8 Sept.

To provide growers with an indication of the overall BLS risk associated with different pepper types and cultivars, we grouped and ranked these according to their relative susceptibility to the disease. Tentative groupings and rankings were based on percent BLS, defoliation ratings, and AUDPC values at QSND. Some of these preliminary rankings also took into consideration the results from previous trials at this location and our observations from growers' fields in central Kentucky (Rowell et al., 1999 and D. Slone, unpublished).

Race determinations. To determine which $\mathrm{Xcv}$ races were present in the QSND trials at the end of the season, symptomatic leaf samples were collected from 'X3R Ironsides', 'Boynton Bell', 'Lexington', and 'King Arthur'. A composite sample of all the bell cultivars in the trial was also collected. These and samples from jalapeño cultivars 'X3R Ixtapa' and 'Grande' were collected at QSND on 30 Sept. (36 d after final harvest).

Samples were also collected from affected specialty cultivars 'Delicias', 'Ballpark' (jalapeño), 'Biscayne', 'Aruba' (cubanelle), 'Tuxtlas' (serrano), 'Santa Fe Grande', 'Hungarian Heat' (hot wax), and 'Ancho Giagantia' (poblano) at LEX on 4 Oct (28 days after the final harvest). All samples were sent to Dr. David Ritchie, Department of Plant Pathology, North Carolina State University, for race determinations where isolates were inoculated onto leaves of 'Early Calwonder' and three nearisogenic lines carrying $B s l, B s 2$, or $B s 3$ (Hibberd et al., 1987). Dr. Ritchie's laboratory also conducted tests to determine whether these isolates were resistant to copper and streptomycin.

\section{Results and discussion}

As in previous years, it was our intention to encourage disease development and evaluate resistance at QSND while keeping the LEX trial free of BLS. A uniform and severe natural epidemic developed in the adjacent bell and hot/ specialty cultivar trials at QSND after more than 12 inches $(>30 \mathrm{~cm})$ of rainfall occurred during the period of 12 June to 12 July. The disease was first observed in the hot/specialty pepper trial.

In spite of a 7-d spray program at LEX, BLS developed in 17 of the 49 hot and specialty cultivars. The disease, however, did not spread beyond the individual cultivar plots that were initially infected as indicated in Tables 4 and 6. No symptoms occurred in the adjacent bell pepper trial where cultivars were evaluated for yield and quality.

Bell cultivars. Total marketable yields, gross returns, and fruit quality characteristics for bell cultivars grown at LEX are shown in Table 1. Yields, gross returns, and disease resistance parameters are shown for the same cultivars grown at QSND in Table 3. Most of the cultivars grown under BLS-free conditions were very high yielding with 12 that were not significantly different from the top yielding cultivar Four Star (RPP 6088,32 tons/acre, $72 \mathrm{t} \cdot \mathrm{ha}^{-1}$ ). There were, however, a number of significant and economically important differences in yields among the same cultivars under heavy disease pressure at QSND where marketable yields ranged from 3 to 19 tons/acre (6.7 to $42.6 \mathrm{t} \cdot \mathrm{ha}^{-1}$, Table 3). By 12 July, susceptible cultivars 'King Arthur' and 'Vivaldi' had $80 \%$ or more of the plants with symptoms at this location.

The highest yielding group at QSND included 'X3R Ironsides', HMX 9646, 'X3R Chalice' (PS 214596), 'X3R Aristotle' (PS 7273823), and 'X3R Red Knight'. 'Boynton Bell', one of the highest yielding and consistently most resistant cultivars in previous trials, fell into an intermediate yield group that included 'Crusader' (RPP 6110), 'Lexington', ACX 209, 'Defiance' (XP 12292), 'Legionnaire' (RPP 6089-VP), and 'Four Star' (Table 3). As expected, susceptible cultivars 'King Arthur', 'Consul', and 'Vivaldi' were among the lowest yielding with the most disease in the QSND trial.Average percentage ofleaves with BLS symptoms ranged from $79 \%$ to $82 \%$ (Table 3 ) for the three susceptible checks. As in previous trials at this location (Rowell et al., 1999), 'X3R Wizard' proved to be susceptible and low yielding under heavy disease pressure. 'Bennington' (EX 2670168) also appeared to be somewhat susceptible and was low yielding under these conditions.

The degree of susceptibility to BLS appeared to have had a direct impact on marketable yields among cultivars tested at QSND (Fig. 1). In most cases, the greater the incidence and severity of BLS, the lower the yield as indicated by a highly significant negative association between AUDPC values and total marketable yields $(r=-0.76, P<0.001)$. There was an even stronger negative association between the degree of defoliation and total marketable yields $(r=-$ $0.85, P<0.001)$ among cultivars at QSND.

Resistance to BLS was relatively high $(\leq 30 \%$ BLS and AUDPC values $<2000$ ) for eight out of 13 entries that had resistance to races 1,2 , and 3 (Bs2 gene). There were important differences 
Table 6. Yield and fruit observations from single plots of specialty pepper cultivars at Lexington, Ky.

\begin{tabular}{|c|c|c|c|c|c|c|}
\hline \multirow[b]{2}{*}{$\begin{array}{l}\text { Type } \\
\text { Cultivar }\end{array}$} & \multirow[b]{2}{*}{$\begin{array}{c}\text { Seed } \\
\text { source }^{\mathrm{z}}\end{array}$} & \multirow[b]{2}{*}{$\begin{array}{c}\text { Market yield } \\
{\text { (tons/acre })^{\mathrm{y}}}\end{array}$} & \multirow[b]{2}{*}{ BLS $^{\mathbf{x}}$} & \multicolumn{3}{|c|}{ Fruit characteristic } \\
\hline & & & & $\begin{array}{c}\text { Avgw }^{\mathrm{w}} \\
\text { length (inch) }\end{array}$ & $\begin{array}{c}\text { Avg }^{w} \\
\text { diam (inch) }\end{array}$ & $\begin{array}{c}\text { Avg }^{w} \\
\text { wt (g) }\end{array}$ \\
\hline \multicolumn{7}{|l|}{ Serrano } \\
\hline Tuxtlas & PS & 24.4 & 2 & 3.4 & 0.8 & 11 \\
\hline Tampico Fiesta & $\mathrm{HN} / \mathrm{AS}$ & 20.2 & & 3.0 & 0.5 & 8 \\
\hline Serrano Chili & PS & 18.0 & & 2.2 & 0.5 & 6 \\
\hline Serrano Tampiqueno & RU & 12.7 & & 2.0 & 0.5 & 4 \\
\hline \multicolumn{7}{|l|}{ Anaheim } \\
\hline Mexiheim & SW & 32.1 & 3 & 6.2 & 1.6 & 48 \\
\hline Anaheim TMR 23 & PS & 30.9 & & 6.2 & 1.6 & 45 \\
\hline Garden Salsa & PS & 25.2 & 1 & 5.7 & 1.3 & 37 \\
\hline \multicolumn{7}{|l|}{ Poblano/Ancho } \\
\hline Ancho Villa & RG & 28.9 & 2 & 4.4 & 2.7 & 95 \\
\hline Ancho Ranchero & RG & 26.5 & & 3.5 & 2.5 & 89 \\
\hline Ancho San Martin & SW & 24.5 & & 3.8 & 2.4 & 77 \\
\hline Ancho 101 & RU & 20.3 & 2 & 3.7 & 2.6 & 61 \\
\hline Ancho Gigantia & RU & 12.5 & 3 & 3.3 & 2.5 & 44 \\
\hline \multicolumn{7}{|l|}{ Italian/Cubanelle } \\
\hline ACX 500 & $\mathrm{AC}$ & 39.0 & 1 & 6.5 & 2.4 & 74 \\
\hline Aruba & RG & 34.1 & 1 & 6.0 & 2.5 & 101 \\
\hline Biscayne & RU & 30.6 & & 5.6 & 2.1 & 84 \\
\hline Corno Di Toro & RU & 27.7 & 2 & 5.7 & 2 & 74 \\
\hline Giant Aconcagua & RU & 22.6 & 1 & 5.6 & 2.4 & 86 \\
\hline \multicolumn{7}{|l|}{ Hot banana/wax } \\
\hline Romanian Hot Hybrid & RU & 38.3 & & 5.5 & 2.8 & 94 \\
\hline Hungarian Heat & RU & 36.5 & & 7.0 & 1.6 & 39 \\
\hline Hungarian Yellow Wax & RU & 33.8 & & 4.3 & 1.3 & 34 \\
\hline X3R Hot Spot (Bs2) & PS & 33.5 & & 5.7 & 1.4 & 46 \\
\hline Inferno & PS & 32.5 & & 7.0 & 1.6 & 59 \\
\hline Santa Fe Grande & PS & 27.7 & & 2.8 & 1.4 & 21 \\
\hline ACX 400 & $\mathrm{AC}$ & 26.2 & & 5.1 & 1.4 & 28 \\
\hline \multicolumn{7}{|l|}{ Sweet banana/wax } \\
\hline Pageant (Bs2) & RG & 41.2 & & 6.4 & 1.8 & 61 \\
\hline Gypsy & RU & 35.6 & & 4.7 & 2.2 & 79 \\
\hline Market Sweet & RU & 30.4 & & 6.3 & 1.8 & 58 \\
\hline Banana Supreme & RU & 30.4 & & 6.0 & 1.6 & 59 \\
\hline Sweet Banana & RU & 25.5 & & 4.8 & 1.5 & 40 \\
\hline \multicolumn{7}{|l|}{ Miscellaneous } \\
\hline Super Chili & RU & 10.2 & & 2.3 & 6.2 & \\
\hline Mesilla & PS & 16.0 & & 7.7 & 1.2 & 44 \\
\hline Habanero & $\mathrm{H}$ & 10.9 & & 2.0 & 1.3 & 10 \\
\hline
\end{tabular}

${ }^{\mathrm{z}} \mathrm{RU}=$ Rupp Seeds, Wauseon, Ohio; RG = Rogers Brand (Novartis Seeds), Boise Idaho; PS = Petoseed (Seminis Vegetable Seeds), Saticoy, Calif.; AS = Asgrow Seed Co. (Seminis Vegetable Seeds), Saticoy, Calif.; $\mathrm{AC}=$ Abbott \& Cobb Seed Co., Feasterville, Pa.; SW = Seedway, Elizabethtown, Penn.; HN = HungNong Seed America, Gilroy, Calif.; $\mathrm{H}=$ Hollar \& Co., Rocky Ford, Colo.

y 1.0 ton/acre $=2.24 \mathrm{t} \cdot \mathrm{ha}^{-1}$

${ }^{x}$ Bacterial spot symptoms were observed in some plots and may have affected yields of those cultivars: $1=$ plots with mild infection, $2=$ plots with mild to moderate infections, 3 = plots that had moderate to severe infections. A blank in this column indicates that no symptoms were observed; blanks or numbers do not imply resistance or tolerance.

wAverage of a sample of 10 fruit (length and width, 1.0 inch $=2.54 \mathrm{~cm}$ ); $1 \mathrm{~g}=0.04 \mathrm{oz}$.

vAverage wall thickness of five typical fruit $(0.10 \mathrm{inch}=0.25 \mathrm{~cm})$.

"Visual fruit appearance ratings where $\mathrm{l}$ = worst, 9 = best, taking into account overall attractiveness, shape, color, and uniformity.

$\mathrm{t} \mathrm{g}=$ light green; $\mathrm{mg}=$ medium green; $\mathrm{dg}=$ dark green; $\mathrm{vdg}=$ very dark green; gy = greenish yellow; py = pale yellow; ly = lemon yellow.

SStaking with one or more strings may be required using double rows on plastic with drip as indicated by " $\mathrm{r}$ " (required) = cultivars requiring staking/support; "b" (benefit) = cultivars that may benefit from staking; "p" = cultivars that may need staking under windy conditions or with heavy fruit loads.

in epidemic development and yields among $B s 2$ cultivars at QSND which could be grouped as "highly resistant" ('X3R Aristotle', 'X3R Chalice', 'X3R Ironsides', 'X3R Red Knight', HMX 9646, ACX 209), "resistant” ('Legionnaire', 'Boynton Bell', 'Lexington'), and “tolerant” ('Defiance', 'Four Star', 'Cru- sader') to BLS based on clear-cut statistical differences among AUDPC values (Table 3, Fig 1). 'Crusader' was relatively high yielding in spite of its high AUDPC value. 'Bennington' could be counted among cultivars in the tolerant group in spite of its lack of $B s 2$.

Fruit quality characteristics for bell cultivars are shown in Table 1 . 'Bennington' and ACX 209 received the highest fruit appearance ratings that were equal to ratings for 'X3R Wizard' (our standard for attractive fruit). 'Bennington' fruit were as dark or darker green than fruit of 'X3R Wizard'. Other cultivars received acceptable appearance 


\begin{tabular}{|c|c|c|c|c|}
\hline \multicolumn{3}{|c|}{ Fruit characteristic } & \multirow[b]{2}{*}{$\begin{array}{c}\text { Plant } \\
\text { support }^{\text {suppos }}\end{array}$} & \multirow[b]{2}{*}{ Comments } \\
\hline $\begin{array}{c}\text { Wall } \\
\text { thickness (inch) }\end{array}$ & $\begin{array}{c}\text { Appearance } \\
\text { rating }^{u}\end{array}$ & Color $^{t}$ & & \\
\hline 0.12 & 8 & $\mathrm{mg}-\mathrm{dg}$ & $\mathrm{b}$ & Very nice; long and thick \\
\hline 0.10 & 7 & mg-dg & $\mathrm{b}$ & Long, not as thick as Tuxtlas \\
\hline 0.11 & 6 & $\mathrm{mg}$ & $\mathrm{b}$ & Short (longer than S. Tampiqueno) \\
\hline 0.10 & 5 & $\mathrm{mg}-\mathrm{dg}$ & $\mathrm{b}$ & Short and stubby \\
\hline 0.15 & 6 & $\mathrm{mg}$ & $\mathrm{r}$ & More crescent shapes than other 2 anaheims \\
\hline 0.16 & 7 & $\mathrm{mg}$ & $\mathrm{r}$ & \\
\hline 0.13 & 8 & $\mathrm{mg}-\mathrm{dg}$ & $\mathrm{r}$ & Very nice, uniform \\
\hline 0.19 & 8 & $\mathrm{mg}$ & $\mathrm{r}$ & Very nice; mostly four-lobed \\
\hline 0.17 & 5 & $\mathrm{dg} / \lg$ & $\mathrm{r}$ & Two distinct types; cultivar mix? \\
\hline 0.15 & 7 & $\mathrm{dg}$ & $\mathrm{r}$ & Two- and three -lobed \\
\hline 0.17 & 4 & vdg & $\mathrm{r}$ & Small; 30-50\% 2-lobed \\
\hline 0.15 & 4 & $\mathrm{vdg}$ & $\mathrm{r}$ & Small; mostly 3-lobed \\
\hline 0.15 & 6 & $\lg$ & $\mathrm{b}$ & \\
\hline 0.17 & 6 & $\lg$ & $\mathrm{b}$ & \\
\hline 0.15 & 5 & gy & $\mathrm{b}$ & Many crescent-shaped \\
\hline 0.18 & 8 & $\mathrm{mg}$ & $\mathrm{b}$ & Very nice; anaheim color \\
\hline 0.15 & 5 & gy & $\mathrm{b}$ & \\
\hline 0.25 & 6 & $\lg$-py & $\mathrm{b}$ & Very large; pointed pimiento shape \\
\hline 0.12 & 4 & gy & $\mathrm{p}$ & Mostly 'C'-shaped \& mishapen \\
\hline 0.13 & 6 & py-ly & $\mathrm{b}$ & Large, blunt, pimiento shape \\
\hline 0.17 & 7 & gy & $\mathrm{p}$ & Somewhat curved \\
\hline 0.16 & 6 & gy & $\mathrm{p}$ & \\
\hline 0.12 & 7 & py & $\mathrm{p}$ & Jalapeno size and shape; uniform \\
\hline 0.13 & 5 & py & $\mathrm{p}$ & Many 'C'-shaped and mishapen \\
\hline 0.18 & 6 & py-ly & $\mathrm{p}$ & Nice, thick, some apostrophe-shaped \\
\hline 0.19 & 7 & py & $\mathrm{p}$ & Orange at maturity \\
\hline 0.19 & 6 & py & $\mathrm{p}$ & Nice, thick \\
\hline 0.15 & 6 & gy-ly & $\mathrm{b}$ & Nice, some 'C'-shaped \\
\hline 0.15 & 4 & gy-py & $\mathrm{p}$ & Many ' $\mathrm{C}$ '-shaped and mishapen \\
\hline & 4 & & & Numerous small fruit difficult to pick! \\
\hline & & & $\mathrm{b}$ & Very long, thick cayenne type \\
\hline & & & $\mathrm{b}$ & Uniform and high yielding; orange at maturity \\
\hline
\end{tabular}

ratings while 'Crusader' and 'Lexington' were rated lower. 'Lexington' fruit quality, however, would have been rated much higher at an earlier harvest date according to our observations.

Cultivars that were in the highest yielding groups under both epidemic and disease-free conditions and which had acceptable fruit quality ratings included 'X3R Aristotle', 'X3R Ironsides', 'X3R Chalice', and 'X3R Red Knight'. The only disadvantage to ' $\mathrm{X} 3 \mathrm{R}$ Ironsides' was lighter colored fruit, similar in color to 'King Arthur', HMX 9646, and 'Four Star'. Although 'X3R Chalice' is yellow at full maturity, it was possible to harvest this cultivar at the mature green stage.

The susceptible cultivar 'Consul' was very high yielding with acceptable quality under BLS-free conditions. The susceptible elongate cultivar 'Vivaldi' set fruit early and had higher yields than indicated by the data in Table 1 . We had decided that this cultivar might be more appropriate for a colored pepper market and waited until full red maturity before harvesting. As a result, there were more culls associated with fruit rots and a fairly large number of green fruit remained on the plants after the final trial harvest on 30 Aug.

Jalapeños. Yields and fruit characteristics of the 17 jalapeño pepper culti- vars grown in single plots at LEX and QSND are shown in Tables 4 and 5, respectively. Three of these cultivars carry the Bs2 gene. Although we intended to keep the LEX trial free of BLS, symptoms developed on a number of cultivars (Table 4). In spite this, most jalapeño cultivars had extremely high marketable yields ranging from 24 to 42 tons/acre ( 54 to $94 \mathrm{t} \cdot \mathrm{ha}^{-1}$ ) with several cultivars exceeding the standard 'Mitla' (Table 4). Among these, RPP 7042-VP (similar to 'Grande') had the most attractive fruit followed by 'Ballpark'. Cultivars without the Bs2 gene that were exposed to severe disease pressure at QSND had very low yields 
Table 7. Tentative ranking of pepper types and cultivars by their relative susceptibility tobacterial spot.

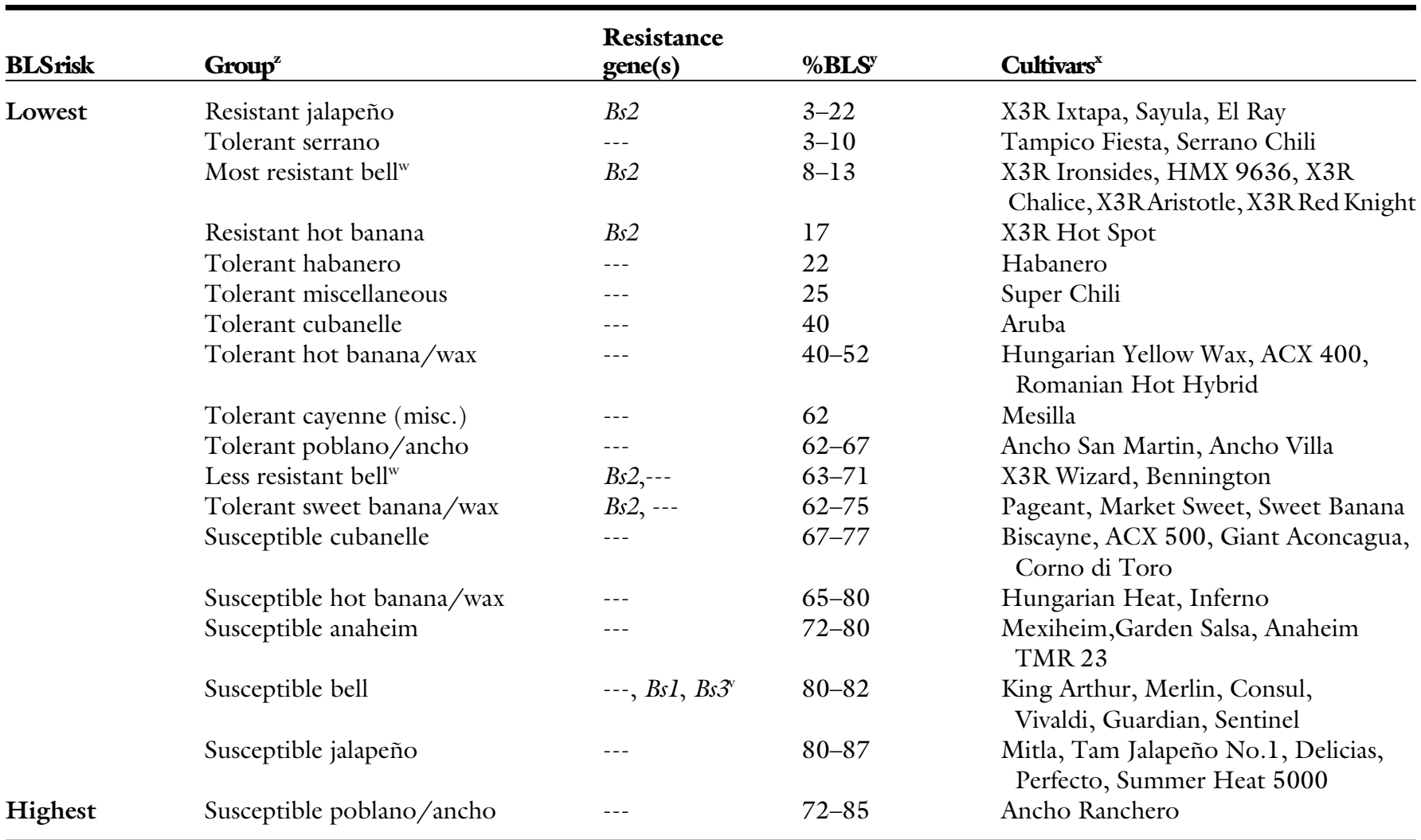

${ }^{\mathrm{z}}$ Cultivars within types (bell, jalapeño, or hot/specialty types in Table 6 ) grouped as 1 ) resistant = having Bs2 gene and high yielding with fewer symptoms and defoliation overall than 2) tolerant = having no major resistance gene but with considerably fewer symptoms and yielding more marketable fruit than 3 ) susceptible = little to no marketable yield with extensive foliar symptoms and defoliation.

y\% BLS = range of the avgerage percentages of leaves with bacterial spot symptoms under severe epidemic conditions at Quicksand, Ky.; data are from two assessment dates and one or more cultivars (Tables 3,4 , and 5 .)

${ }^{x}$ Not all cultivars tested are listed; others may be equally resistant, tolerant, or susceptible.

"Bell cultivars that were the most resistant with highest yields and gross returns (Table 3). Less resistant bell are those cultivars (with or without Bs2) with relatively high area under the disease progress curve (AUDPC) values, \%BLS, and defoliation.

${ }^{\mathrm{v}}$ Cultivars having $B s 1, B s 3$, or both were as susceptible as those with no major resistance genes in 1995 trials.

(1.5 to 5 tons/acre, 3.4 to $11 \mathrm{t} \cdot \mathrm{ha}^{-1}$, Table 5). BLS symptoms and defoliation were low on all three resistant cultivars; yields of 'X3R Ixtapa' and 'El Ray' were relatively high under these conditions while yields of the third resistant cultivar ('Sayula') were quite low.

Serranos. Marketable yields for the four serrano cultivars at LEX ranged from 12 to 24 tons /acre (27 to $54 \mathrm{t} \cdot \mathrm{ha}^{-1}$ ) with 'Tuxtlas' having the highestyield and most attractive fruit in spite of BLS infection (Table 6). Under severe disease pressure at QSND, 'Tampico Fiesta' and 'Serrano Chili' appeared to show some tolerance to BLS in spite of the absence of any major resistance gene (Table 5 ).

Anaheims. Yields of the three anaheim cultivars ranged from 25 to 32 tons/acre (56 to $72 \mathrm{t} \cdot \mathrm{ha}^{-1}$ ) at LEX; 'Mexiheim' was the highest yielding while 'Garden Salsa' had smaller, but more attractive fruit (Table 6). 'Mexiheim' was also the highest yielding at QSND under heavy disease pressure although yields were very low; all anaheim cultivars appeared to be very susceptible to BLS.

Poblanos/anchos. Yields at LEX ranged from 12 to 29 tons / acre (27 to $\left.65 \mathrm{t} \cdot \mathrm{ha}^{-1}\right)$ where 'Ancho Villa' was the highest yielding with the largest and most attractive fruit (Table 6); fruit of this cultivar, however, were four-lobed, which might be a disadvantage if buyers prefer more pointed fruit. All poblano/ ancho cultivars were extremely susceptible to BLS (Table 5 ).

Italian/cubanelles. Yields for the five Italian/cubanelle or frying peppers ranged from 23 to 39 tons/acre (51 to $87 \mathrm{t} \cdot \mathrm{ha}^{-1}$ ) at LEX (Table 6). ACX 500 had the highest yield while 'Aruba' (34 tons/acre, $76 \mathrm{t} \cdot \mathrm{ha}^{-1}$ ) had the largest fruit size. 'Corno di Toro' had the most attractive fruit although they were medium green in color instead of the usual light green or greenish yellow. All of these cultivars appeared to be quite susceptible to BLS with the possible exception of 'Aruba' which had less disease and yielded 5 tons/acre (vs. 0 to
1.7 tons/acre or 0 to $3.8 \mathrm{t} \cdot \mathrm{ha}^{-1}$ for the other cultivars) under heavy disease pressure at QSND (Table 5).

Hot banana/wax. Seven hot banana (or hot wax) type peppers were tested including one having the $B s 2$ gene ('X3R Hot Spot'). Fruit size and type differed considerably among cultivars in this group; the large-fruited and thick-walled 'Romanian Hot Hybrid' had the highest marketable yield at LEX (38 tons/acre, $85 \mathrm{t} \cdot \mathrm{ha}^{-1}$ ). 'X3R Hot Spot' had the highest appearance rating among the long-fruited cultivars (Table $6)$. This resistant cultivar also had the highest yields under heavy disease pressure at QSND with much less disease and defoliation than the other cultivars in this group (Table 5).

Sweet banana/wax. The five sweet banana (or sweet wax) cultivars included one having the $B s 2$ gene ('Pageant'). Yields at LEX ranged from 25 to 41 tons/acre (56 to $92 \mathrm{t} \cdot \mathrm{ha}^{-1}$, Table 6); 'Pageant' was the highest yielding followed by 'Gypsy'. The popular cultivar 
Banana Supreme yielded 30 tons/acre $\left(67 \mathrm{t} \cdot \mathrm{ha}^{-1}\right)$. Yields for all cultivars were much lower at QSND under severe BLS epidemic conditions (Table 5). All cultivars, including 'Pageant' were affected by BLS. 'Pageant' appeared to be segregating for resistance or was perhaps a mixture of susceptible and resistant plants with 12 out of 16 plants appearing to be very susceptible. 'Market Sweet', a susceptible cultivar, had about the same level of disease as 'Pageant'.

Miscellaneous Specialty PepPers. One habanero pepper (Capsicum chinense), one home garden hot pepper ('Super Chili'), and a large-fruited cayenne type hot pepper ('Mesilla') were included in the RACE trials. Yields of each cultivar were high at LEX but reduced by severe BLS pressure at QSND (Tables 6 and 5, respectively). Although yields were reduced at QSND, the habanero pepper had only $22 \%$ of its leaves with symptoms and very little defoliation in spite of not having any known BLS resistance gene (Table 5).

Xcv races. Although eleven Xcv races have beenidentified to date (Ritchie et al., 1998), only races 1, 3, 4, and 6 are of economic importance in the United States at this time. Races 1,3 , and 6 (1995) and races 1, 3, and 4 (1996) had been recovered at the end of the season from previous trials at QSND after susceptible transplants had been inoculated with races 1,2 , and 3 (Rowell et al., 1999). Races 3 and 6 were detected at the end of the 2000 season in the QSND bell pepper trial. Race 6 was detected in one of only two samples collected from the QSND hot/specialty trial. Only race 3 was detected in samples collected from the affected hot and specialty cultivars at LEX.

Race 6, for which resistant cultivars are not currently available, was found associated with some of the cultivars appearing to be the most resistant in the QSND trial ('X3R Ironsides' and jalapeño 'X3R Ixtapa') while only race 3 was found on leafsamples from 'Boynton Bell', 'Lexington', and 'King Arthur'. Several cultivars were high yielding with few BLS symptoms and little defoliation in spite of the severe epidemic and the presence of race 6 in the trial field. All
$\mathrm{Xcv}$ isolates from the QSND trials were sensitive to both copper and streptomycin indicating that these materials can still be effective in controlling BLS under certain conditions in Kentucky.

Pepper types, cultivars, and bacTERIAL SPOT RISK. Eastern and central Kentucky growers experienced periodic devastating BLS epidemics before the widespread planting of $B s 2$-gene resistant bell pepper cultivars. Our studies indicate that there is considerable variation in the degree of resistance among these cultivars and that some "resistant" cultivars are much more susceptible than others. There is increasing interest in Kentucky and other states in growing hot and specialty peppers, most of which do not carry any major resistance gene. While there is a significant risk of serious BLS epidemics associated with the production of some of these cultivars, others can be grown with less likelihood of disaster (Table 7), especially with timely protectant chemical applications.

As part of an overall pest management program, we recommend that pepper growers produce their own transplants using treated seed whenever possible and to practice strict greenhouse and fieldsanitation. We recommend that growers use horticulturally acceptable resistant cultivars in conjunction with copper plus maneb protectant spray treatments. Further research will help determine to what extent these treatments can be minimized with resistant cultivars.

\section{Literature Cited}

Campbell, C. L., and L. V. Madden. 1990. Introduction to plant disease epidemiology. Wiley, New York.

Hibberd, A.M., M.J. Bassett, and R. Stall. 1987. Allelism tests of three dominant genes for hypersensitive resistance to bacterial spot of pepper. Phytopathology 77:1304-1307.

Ritchie, D.F., C.S. Kousik, and T.C. Paxton. 1998. Response of bacterial spot pathogen strains to four major resistance genes in pepper, p. 14. In: Proc. Natl. Pepper Conf., San Antonio, 13-15 Oct. 1998.

Rowell, B., R.T. Jones, W. Nesmith, and J.C. Snyder. 1999. Comparison of resistant cultivars for management of bacterial spot in peppers. HortTechnology 9:641-650.

\section{Evaluation of Carrot Cultivars for Cut and Peel Processing in Prince Edward Island, Canada, 1997-98.}

\author{
K.R. Sanderson ${ }^{1}$ and \\ S.D. MacKinnon ${ }^{2}$
}

Additional indeX words. Daucus carota, yield

Summary. Twelve carrot (Daucus carota) cultivars were evaluated at two sites in 1997 and 13 carrot cultivars were evaluated at one site in $\mathbf{1 9 9 8}$ for their potential use as cut and peel carrots. The cultivars were evaluated for total yield, marketable yield and root characteristics. Yields were quite variable with the highest yielding cultivars having the shortest root length. Of the cultivars tested, 'Presto' produced high marketable yields, root diameters and root weights, however, it was very short. 'Indiana' produced consistent yields and stand with a good root length. 'Bolero', 'Presto' and Indiana' were the best performing cultivars for cut and peel production in Prince Edward Island, Canada.

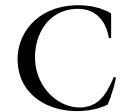
arrots have been an important vegetable crop in Prince Edward Island (PEI), Canada, with a farm gate value of about CDN \$ 2.5 million (PEI Department of Agriculture and Forestry, 1999). The crop is primarily grown for the fresh pack wholesale and retail market and produces an average yield of about 13 tons/acre (29.1 th.ha ${ }^{-1}$ ). Recently, a small acreage of processing

\footnotetext{
The cost of publishing this paper was defrayed in part by payment of page charges. Under postal regulations, this paper therefore must be hereby marked advertise ment to indicate this fact.

${ }^{1}$ Research biologist, Crops and Livestock Research Centre, Agriculture and Agri-Food Canada, 440 University Ave., Charlottetown, PEI, Canada, ClA 4N6.

${ }^{2}$ Vegetable development officer, Prince Edward Island Department of Agriculture and Forestry, Charlottetown, PEI, Canada, ClA 7N3
} 